\title{
Comparative Study of Games and Think-Pair-Share on Pre-Service Teachers' Performance in Classification of Living Organisms.
}

\author{
Joseph Parker \\ Department of Science Education, Enchi College of Education, P. O. Box 44, Enchi. WN/R- Ghana. \\ kerpack@yahoo.com \\ DOI: 10.29322/IJSRP.11.05.2021.p11307 \\ http://dx.doi.org/10.29322/IJSRP.11.05.2021.p11307
}

\begin{abstract}
The purpose of the study was to determine the effectiveness of game-based learning approach and think-pair-share teaching approach on teacher trainees' performance. This study adopted a comparative research design. The study was carried out in Enchi College of Education in the Aowin Municipality in the Western North Region of Ghana. Stratified, simple random and systematic sampling techniques were used to select 160 respondents for the study.

The instrument used for the data collection was test. The findings revealed that, the mean score values of post-test results of level 300 and 100 of students exposed to game-based learning approach were significantly higher than the mean score values of post-test of level 300 and 100 of students exposed to think-pair-share learning technique. This implies that, the game-based learning approach had greater impact on students' performance in classification of living organisms than think-pair-share learning technique.
\end{abstract}

Keywords: comparative; game-based learning; think-pair-share; classification; taxonomy.

\section{Introduction}

Education has long been recognised as the central element in the development of human personality (Yasseen, 2010). It is viewed as the backbone of national development and a crucial factor in human resource development of which science education has a role to play. Science as a field of study has a controlling influence over people's lives and enables humans to understand the nature and things around them. Science education emphasizes a method of inquiry and a systematic way of processing knowledge about the physical world to the learners to promote scientific literacy among citizens on matters directly affecting their own lives and the society so that they can make decisions based on information and understanding. It is therefore important that teacher trainees acquire adequate knowledge about classification of things around humanity by observing similar characteristics exhibited by organisms.

Humans like to collect and study things and collection of things usually must be accompanied by classification (Lina, 2004). Aristotle, 4th century BC (384 to 322 BC), a Greek philosopher, divided organisms into two groups - plants and animals as a way of classifying living organisms. Aristotle was the earliest to attempt a more scientific basis for classification. He used simple morphological characters to classify plants into trees, shrubs and herbs. To make it easier to study living organisms, biologists have sorted living organisms into groups. This sorting is called classification. Taylor, Green and Stout (1998), defines classification as grouping things together on the basis of features they have in common. According to them, if our senses are besieged by an overwhelming number of stimuli, we begin to cope and make sense of things by classifying them.

In science, the practice of classifying organisms is called taxonomy. Taxonomy is that part of biology dedicated to describing, and classifying organisms (Madar, 1997). Biological classification is the sorting of living things into groups according to their common characteristics (Asabere-Ameyaw \& Haruna, 2004).

Biological classification (taxonomy) aims to simplify and order the immense diversity of life into coherent units called taxa that have widely accepted names and whose members share important properties. To avoid confusion, biologists have given each kind of organism its own unique, two-word name called a binomial (meaning 'two names'). This idea was first thought of in 1735 by Linnaeus, a Swedish scientist. Linnaeus wanted to make sure that scientists all over the world could communicate about living organisms, even though they spoke different languages and so had different names for the same kind of organism.

Classification has many uses. First, it helps scientists to sort organisms in order. Second, it helps them to identify new organisms by finding out which group they fit. Third, it is easier to study organisms when they are sorted in groups. The issue pertinent to this 
research is the need for students learning science in developing countries to begin to see science as an everyday practical reality, not just as a set of scientific procedures and activities with no relationship to real life.

For this reason, creative approach of teaching such as game-based learning approach and think-pair-share learning technique must be adopted by science teachers.

Educational games are sets of competitive activities which consist of strict rules to reach desired goals such as acquiring or improving knowledge and skills (Boctor, 2012; Haggart, 2001; Webb, Simpson, Denson and Duthie, 2012). They differ from non-educational games where the purpose is primarily on entertainment. Educational games are innovative teaching tools that have been shown to promote critical thinking, enhance clinical confidence building and promote problem solving skills (Anyanwu, 2014). According to Hughes (1999), playing is different from learning and working. Playing is an activity that helps to achieve complete development, both physically, intellectual, social, moral, and emotional.

Playing is one of learning principles of students in schools. Learning activity of children in schools should be managed with playing so that the children can be happy and comfortable. Teacher-trainees therefore need to be exposed to game-based learning approach so as to inculcate in them the competence and culture in using educational games in their teaching. Andang (2006) who contended that through playing activity, children can acquire learning that consists of cognitive, social, emotion, and physical development aspects. Educational games are more social and can incorporate many aspects of civic and political life (Bainbridge, 2007). As pedagogical devices, games are extremely useful and are effective for dealing with problem solving and key concepts in the teaching and learning of science. Apart from inviting students to learn curriculum content in a fun and relaxed manner, games also expose students to other skills development during game play via sequential, verbal, visual and kinetic and other game-based activities (Fuszard, 2001). They allow for increasing involvement of students and are efficient in overcoming significant deficits of traditional teaching methods (Kapp, 2012; Sheldon, 2012).

From the above literature, the researcher is of the view that educational games are seen as entertainment rather than a method of learning since games have rules, definitive objectives, measurable goals and provide an interactive experience that promotes a sense of achievement for all participants which tend to motivate and engage students, give immediate feedback, promote cognitive growth and enhance skills development.

Think-pair-share technique on the other hand, is a modern teaching strategy which is aimed to provide students the achievement and aims to stimulate their energies and develop their abilities. It is also suitable for students of all ages and those engaging in cooperative learning for the first time (Ahmed, 2016). It is a collaborative learning strategy in which students work together to solve a problem or answer a question. This technique requires students to think individually about a topic or answer to a question and share ideas with classmates.

Ajiboye and Ajitoni (2008) observed that children learn best by being interested fully in their own work, by puzzling, experimenting, verifying their own suppositions and drawing conclusions on the strength of evidence which they have collected themselves.

Ruiz-Primo (2011) opined that in addition to the benefits gained through cooperative learning and increased wait time, the aspect of formative assessment that the Think-Pair-Share strategy provides is valuable to the learning process. Using Think-Pair-Share allows the teacher to gain insight into the quality of student understanding. When teachers are able to measure their students' understanding, they can use this information to alter their instruction in a way that would be more beneficial to learners.

Think-pair-share pedagogy allows the teaching and learning process to be less teacher centred by giving more interdependence to students for participating in the activities by offering "processing time" and "wait-time", which greatly helps students to think deeper. This view is similar to what Yerigan (2008) writes that the "Think-Pair-Share is an active learning strategy that provides processing time for theory, builds in wait time, provides rehearsal, enhances depth and breadth of thinking, increases level of participation, allows the instructor to check for understanding and provides time for instructor to make instructional decisions". Its rationale has a lot in common with that of the constructivist approach as this model requires learners to interact with each other/others at different levels. Therefore, this model encourages learners to be more active during instruction.

According to the original model of think-pair-share, the think phase allows the teacher to pose a question to the class and gives students time to think individually and come up with original answers on their own, the pair phase requires students' pairing up preferably with the student sitting closest to them. At that point, depending on the type of the task and the question, students share their primary thoughts or answers with each other and the share phase, the paired students to share what they agree on with the whole class.

Utama, Marhaeni and Putra (2013) report that Think-Pair-Share approach allows development of self-confidence and speaking skills among English language learners of which science learners cannot be rule out. They attribute this increase to the interaction and motivating effect this model brings. Jebur, Jasim and Jaboori (2012) finds that implementation of this model resulted in higher learning results in a General Physics class. Similarly, Fitzgerald (2013) writes that using Think-Pair-Share led to higher achievement results. Roswati and Radjab (2014) find out that implementing think-pair-share pedagogy enabled their students to become better speakers of the target language in addition to fostering their motivation. McKeachie and Svinicki (2006) stated that following thinkpair-share activities, their students often feel more at ease to participate in a general discussion. Besides, Baleghizadeh (2010) finds in his study that when his students in the second year of Physics programme worked with Think-Pair-Share pedagogy, their wordbuilding abilities improved greatly. Likewise, the study by Sumarsih and Sanjaya (2013) reveal that applying think-pair-share strategy improved the mean of students' scores in their writing class. 
From the above, it can be deduced that there is a positive perception about the impact of educational games and think-pair-share technique on the learning process.

\section{Statement of Problem}

Research within cooperative learning shows that there has been little study conducted on how the use of game-based learning approach and think-pair-share learning technique can improve the performance of teacher trainees in Ghana. This study therefore seeks to compare the effectiveness of game-based learning approach and think-pair-share learning technique as teaching strategies on teacher trainees' performance in Colleges of Education in Ghana. Specifically, the interest is to compare the effectiveness of gamebased learning approach and think-pair-share learning technique on teacher trainees' performance in a specific concept "classification of living organisms."

\section{Objectives of the Study}

The study specifically sought to compare the effectiveness of game-based learning approach and think-pair-share learning technique on teacher trainees' performance in Classification of living organisms in Enchi College of Education in Ghana.

\section{Hypotheses}

The hypothesis to be tested is:

$\mathbf{H}_{0}$ : There is no significant difference in the use of game-based learning approach and think-pair-share learning technique teacher trainees' performance in Classification of living organisms.

$\mathbf{H}_{1}$ : There is significant difference in the use of game-based learning approach and think-pair-share learning technique teacher trainees' performance in Classification of living organisms.

\section{Methodology}

The research design adopted for this study was a comparative research design. Comparative research is the act of comparing two or more things with a view to discovering something about one or all of the things being compared. In comparative study an attempt is made to identify a cause effect relationship between two or more groups.

In this study, comparative study design was used to examine the effectiveness of game-based learning approach and think-pair-share learning technique on teacher trainees' performance in classification of living organisms. The population of the study were teacher trainees in Enchi College of Education in Ghana. stratified, simple random and quota sampling technique were used to sample one hundred and sixty respondents (160). This was made up of eighty (80) male teacher trainees and eighty (80) female teacher trainees. The participants were pre-tested before the intervention and post-tested after the intervention.

The research instrument used to gather data for the study was self-designed achievement test based on the topic treated titled pre-test and post-test. Both tests consisted of ten objective items. The content validity of the test was ascertained by subjecting the instrument to the scrutiny by an expert in the Science Education Department, University of Education, Winneba. The instrument was pilot-tested to ascertain its validity and reliability index.

\section{Stage One: Pre-Treatment Phase}

Prior to the implementation, a pre-test was applied to both levels to determine their equivalence. A pre-test was conducted for 80 level 300 respondents and 80 level 100 respondents separately before they were regrouped into 40 respondents for each level constituting four groups of respondents. Thus 40 level 300 participants were subjected to game-based learning approach and another 40 level 300 participants were also subjected to think-pair-share learning technique through systematic sampling technique. The same procedure was used to select level 100 participants into their game-based learning approach group and think-pair-share learning technique group respectively. This enabled the researcher to compare the performance of the four groups before and after the treatments were given.

\section{Stage two: The treatment Phase}

The think-pair-share learning technique was used by the researcher to teach the participants in both level 300 and level 100 who were grouped under think-pair-share learning technique group

Educational games were used by the researcher to teach the participants in both level 300 and level 100 who were grouped under game-based learning approach group.

\section{Stage Three: Post-Treatment Phase}

After the treatment, a post-test was conducted for both groups. This also helped the researcher to determine whether there is a significance difference between the post-test scores of the treatment groups.

\section{Results and discussion}

The data collected was analysed and results presented in tables one to four based on the hypotheses raised for the study. The null hypotheses were tested at 0.05 level of significance. 
1. $\mathrm{H}_{0}$ : There is no significant difference in the mean scores of the post-test results and pre-test results of level 300 students taught Classification of living organisms using Game-based learning approach.

Table 1: Table 1: Results of descriptive statistics on pre-test and post-test of level 300 teacher trainees exposed to game-based learning approach

\begin{tabular}{llcc}
\hline & $\mathrm{N}$ & Mean & Std. Deviation \\
\hline Pre-test score & 40 & 2.33 & .797 \\
Post-test score & 40 & 6.83 & 1.375 \\
& & & \\
\hline
\end{tabular}

The mean value of post-test results (6.83) differ significantly from the pre-test results (2.33) of level 300 respondents exposed to game-based learning approach. Hence the Null Hypothesis $\left(\mathrm{H}_{0}\right)$ is rejected and there is enough evidence to accept the alternative hypothesis $\left(\mathrm{H}_{1}\right)$. In other words, the introduction of game-based learning approach had potency on students' performance in classification of living organisms.

2. Ho: There is no significant difference in the mean scores of the post-test results and pre-test results of level 300 students taught Classification of living organisms using think-pair-share learning technique.

Table 2: Results of descriptive statistics on pre-test and post-test of level 300 teacher trainees exposed to think-pair-share learning technique

\begin{tabular}{llcc}
\hline & $\mathrm{N}$ & Mean & Std. Deviation \\
\hline Pre-test score & 40 & 2.10 & .955 \\
Post-test score & 40 & 4.37 & .807
\end{tabular}

The mean value of post-test results (4.37) differ significantly from the pre-test results (2.10) of level 300 respondents exposed to think-pair-share learning technique (See Appendix E). Hence the Null Hypothesis $\left(\mathrm{H}_{0}\right)$ is rejected and consequently accept the Alternative Hypothesis $\left(\mathrm{H}_{1}\right)$ that, there is a significant difference in the mean scores in pre-test and post-test results of level 300 students taught Classification of living organisms using think-pair-share learning technique. In other words, the introduction of thinkpair-share learning technique had impact on students' performance in classification of living organisms

3. $\mathrm{H}_{0}$ : There is no significant difference in the mean scores of the post-test results and pre-test results of level 100 students taught Classification of living organisms using game-based learning approach.

Table 3: Results of descriptive statistics on pre-test and post-test of level 100 teacher trainees exposed to game-based learning approach

\begin{tabular}{llcc}
\hline & $\mathrm{N}$ & Mean & Std. Deviation \\
\hline Pre-test score & 40 & 2.03 & 1.025 \\
Post-test score & 40 & 6.45 & 1.239
\end{tabular}

The mean value of post-test results (6.45) differ significantly from the pre-test results (2.03) of level 100 respondents exposed to game-based learning approach. Hence the Null Hypothesis $\left(\mathrm{H}_{0}\right)$ is rejected and accordingly accept the Alternative Hypothesis $\left(\mathrm{H}_{1}\right)$. In affirmation to the above exposition, the introduction of game-based learning approach had great effect on students' performance in classification of living organisms.

4. $\mathrm{H}_{0}$ : There is no significant difference in the mean scores of the post-test results and pre-test results of level 100 students taught Classification of living organisms using think-pair-share learning technique.

Table 4: Results of descriptive statistics on pre-test and post-test of level 100 teacher trainees exposed to think-pair-share learning technique

N Mean $\quad$ Std. Deviation

This publication is licensed under Creative Commons Attribution CC BY. 


\begin{tabular}{lccc}
\hline Pre-test score & 40 & 1.78 & 1.025 \\
Post-test score & 40 & 4.23 & .800
\end{tabular}

The mean value of post-test results (4.23) differ significantly from the pre-test results (1.78) of level 100 respondents exposed to think-pair-share learning technique. Hence the Null Hypothesis $\left(\mathrm{H}_{0}\right)$ is rejected and respectively accept the Alternative Hypothesis $\left(\mathrm{H}_{1}\right)$. In this regard, the introduction of think-pair-share learning technique had potency on student's performance in classification of living organisms.

5. Ho: There is no significant difference in the mean scores of the post-test results of level 300 and level 100 students taught classification using of game-based learning approach and level 300 and level 100 students taught classification using think-pair-share learning technique strategies on students' performance in classification of living organisms.

The mean values of post-test results of level $300(6.83)$ and $100(6.45)$ students exposed to game-based learning approach were significantly greater than the mean values of the post-test results of level $300(4.37)$ and $100(4.23)$ students exposed to think-pairshare learning technique.

Hence the Null Hypothesis $\left(\mathrm{H}_{0}\right)$ is rejected and accordingly accept the Alternative Hypothesis $\left(\mathrm{H}_{1}\right)$. This implies that, the game-based learning approach had greater impact on students' performance in classification of living organisms than think-pair-share learning technique.

Grounded on a $5 \%$ margin of error and the mean differences, the study can confidently and generally conclude that students' performance was advanced and statistically significant with respect to the game-based learning approach as compared to the thinkpair-share technique of learning.

\section{Concluding thoughts}

The results obtained from this study are sufficient to conclude that there is some level of improvement on the performance of teacher trainees when game-based learning approach and think-pair-share learning technique were adopted to teach classification of living organisms in science lessons. However, the mean score values of post-test results of level 300 and 100 students exposed to gamebased learning approach were greater than the mean score values of post-test results of level 300 and 100 students exposed to thinkpair-share learning technique. This implies that, the game-based learning approach had greater impact on teacher trainees' performance in classification of living organisms than think-pair-share learning technique.

In the light of these findings, it is important to pay proper attention to game-based learning approach since it has more positive effect on the performance of teacher trainees' achievement test than think-pair-share learning technique.

\section{References}

Ahmed, M. A. (2016). The effect of (think Pair Share) and (Sequenced Questions) Strategies on Fifth Primary Students Achievement and retention at Sciences. Journal of College of Basic Education, 22 (94), 403 - 442.

Ajiboye, J. O. \& Ajitoni, S. O. (2008). Effects of full and quasi participatory learning strategies on Nigerian senior secondary students' environmental knowledge: Implication for classroom practice. International Journal of Environmental and Science Education, 3, 58-66.

Andang, I. S. (2006). Education Games: Being Smart and Cheerful with Educational Games. Yogyakarta: Media Pillar. Indonesia.

Anyanwu, C. C. (2014). Exploring Students' Experiences of Information and Communication Technology (ICT) Facilitated Feedback: A case study of business management education students at a higher institution in KwaZulu-Natal.

Asabere-Ameyaw, A. \& Haruna, W. Z. (2004). Basic Skills in Practical Biology. SACOST, University of Education, Winneba.

Bainbridge, W. S. (2007). The Scientific Research Potential of Virtual Worlds. Science, 317 (5837), 472-476.

Baleghizadeh, S. (2010). The effect of pair work on a word-building task. Elt Journal, 64 (4), 405-413.

Boctor, S. (2012). ABC's of Parenting: 26 practical lessons for building a healthy and happy home. Mobile, AL: Everygreen Press. 
Fitzgerald, D. (2013). Employing think-pair-share in Associate Degree Nursing Curriculum. Teaching and Learning in Nursing, 8(3), 88-90.

Fuszard, B. (2001) Gaming. In Lowenstein, A. J., Bradshaw, M. J. \& Fuszard, B.

(Eds.) Fuszard's innovative teaching strategies in nursing ( $3^{\text {rd }}$ ed.). Gaithersburg, MD, Aspen Publishers.

Haggart, J. (2001). Walking ten feet tall. Sheffield: Department for Education and Skills.

Hughes, J. (1999). Altered states: Creativity under the influence. New York: Watson-Guptill Publications.

Jebur, M. S., Jasim, H. H. \& Jaboori, H. R. (2012). The effect of using think-pair-share technique on EFL students' achievement in the course of general English. Journal of College of Basic Education, 15(80), 823-838.

Kapp, K. M. (2012). The Gamification of Learning and Instruction. San Francisco: Pfeiffer.

Lina, S. (2004). Certificate biology. Nairobi: East African Educational Publishers.

Madar, J. S. (1997). Inquiry into life. ( $8^{\text {th }}$ ed). USA. McGraw-Hill.

McKeachie, W. J. \& Svinicki, M. (2006). McKeachie's Teaching Tips: Strategies, Research and Theory for College and University Teachers (12 $2^{\text {th }}$ ed.). New York: Houghton Mifflin.

Roswati, Z. M. \& Radjab, D. (2014). Improving Students' Speaking Skill by using Think-Pair-Share Strategy at the second semester of Syariah Class A at language center of UinSuska Riau. English Language Teaching, 2(1), 1-12.

Ruiz-Primo, M. (2011). Informal Formative Assessment: The Role of Instructional Dialogues in Assessing Students' Learning. Studies in Educational Evaluation, 37(1), 15-24.

Sheldon, L. (2012). The Multiplayer Classroom. Boston: Course Technology.

Sumarsih, M. P. \& Sanjaya, D. (2013). TPS as an Effective Technique to Enhance the Students' Achievement on Writing Descriptive text. English Language Teaching, 6(12), 106-113.

Taylor, D.J., Green, N.P.O., \& Stout, G.W. (1998). Biological Science (3 ${ }^{\text {rd }}$ ed). United Kingdom. University Press, Cambridge.

Utama, I. P., Marhaeni, A. \& Putra, I. N. (2013). The Effect of Think Pair Share Teaching Strategy to Students' Self-Confidence and Speaking Competency of the Second Grade Students of SMPN 6. SINGARAJA e-Journal of Postgraduate Program, University of Education, Ganesha, English Study Program of Education, 1, 1-10.

Webb, T. P., Simpson, D., Denson, S. \& Duthie Jr, E. (2012). Gaming used as an Informal Instructional Technique: Effects on Learner Knowledge and Satisfaction. Journal of Surgical Education, 69(3), 330-334.

Yasseen, B. M. B. (2010). The Effect of Teachers' behaviour on Students' behaviour in the classroom. International Forum of Teaching and Studies, 6(1), 1-2.

Yerigan, T. (2008). Getting Active in the Classroom. Journal of College Teaching \& Learning, 5(6), 19-24. 